\title{
Sistem Informasi Geografis Risiko Kemunculan Rip Current Menggunakan Decision Tree C4.5
}

\author{
Made Leo Radhitya*1, Agus Harjoko ${ }^{2}$ \\ ${ }^{1}$ Program Studi S2 Ilmu Komputer, FMIPA UGM, Yogyakarta \\ ${ }^{2}$ Jurusan Ilmu Komputer dan Elektronika, FMIPA UGM, Yogyakarta \\ e-mail: *1leoibel@gmail.com, ${ }^{2}$ aharjoko@ugm.ac.id
}

\begin{abstract}
Abstrak
Salah satu bahaya yang terdapat di daerah pesisir pantai adalah rip current. Rip current merupakan bahaya yang signifikan untuk para pengunjung pantai. Penelitian ini berusaha untuk menyajikan informasi geografis mengenai risiko kemunculan rip current dengan menggunakan decision tree yang dibangkitkan menggunakan algoritma C4.5. Hasil yang menjadi keluaran dari decision tree tersebut berupa risiko kemunculan rip current. Studi kasus pada penelitian ini adalah pantai yang terletak di Pulau Rote, Kabupaten Rote Ndao, Provinsi Nusa Tenggara Timur. Dari hasil evaluasi kinerja sistem, didapatkan nilai rata - rata untuk accuracy sebesar 0,84, nilai rata - rata untuk precision sebesar 0,61, nilai rata - rata untuk recall sebesar 0,68, dan nilai rata - rata F-measure yang didapat sebesar 0,59 dalam rentang nilai 0 hingga 1.
\end{abstract}

Kata kunci-SIG, Rip current, Decision tree, C4.5

\begin{abstract}
One of the dangers that occur at the beach is rip current. Rip current poses significant danger for beachgoers. This paper proposes a method to predict the rip current's occurence risk by using decision tree generated using $C 4.5$ algorithm. The output from the decision tree is rip current's occurrence risk. The case study for this research is the beach located at Rote Island, Rote Ndao, Nusa Tenggara Timur. Evaluation result shows that the accuracy is 0.84 , and the precision is 0.61 . The average recall value is 0.68 and the average F-measure is 0.59 in the range 0 to 1 .
\end{abstract}

Keywords-GIS, Rip current, Decision tree, C4.5

\section{PENDAHULUAN}

$\mathrm{P}$ ariwisata di Indonesia sudah sangat terkenal sejak dulu, terutama pantai-pantai yang sangat banyak dikarenakan Indonesia merupakan negara kepulauan. Pulau rote merupakan salah satu tujuan pariwisata yang juga sedang dikembangkan. Informasi yang disediakan tentang pariwisata di Pulau Rote masih terbilang kurang, terutama informasi tentang keamanan pada setiap pantai di pulau tersebut. Pembuatan sistem informasi geografis berbasis web diperlukan untuk mendukung pembangunan pariwisata ini.

Salah satu bahaya yang terdapat di daerah pesisir pantai adalah rip current. Menurut [1], rip current merupakan bahaya yang signifikan untuk para pengunjung pantai karena kombinasi dari arus cepat, pendalaman saluran, dan potensi untuk menghancurkan gelombang di titik keluar dari robekan. Bahaya rip current ini telah memakan banyak korban di penjuru dunia. Pada penelitian yang dilakukan oleh [2], korban tenggelam yang diakibatkan rip current 
mencapai 78\%, bunuh diri dan kecelakaan kapal mencapai 5\%, kecelakaan terjadi di pelabuhan sekitar $10 \%$ dan sisanya tidak diketahui penyebabnya.

Terdapat beberapa penelitan tentang algoritma $\mathrm{C} 4.5$ yang telah dimodifikasi sehingga performanya lebih meningkat. Penelitian yang dilakukan oleh [3] memodifikasi algoritma C4.5 dengan memadukan metode Bagging dari Breiman dan Boosting dari Schapire yang merupakan metode terbaru saat itu untuk meningkatkan kekuatan prediksi dari classifier learning system. Penelitian selanjutnya yang dilakukan oleh [4] di tahun yang sama adalah tentang peningkatan penggunaan continuous attribute dalam algoritma C4.5. Ternyata modifikasi ini jauh lebih mudah, mengingat kembali bahwa kriteria gain ratio yang membagi gain yang tampak dengan informasi yang tersedia dari split, sehingga tree menjadi lebih sederhana dan lebih akurat.

Penelitian tentang prediksi rip current telah dilakukan oleh beberapa peneliti. Awalnya, [5] telah mencari korelasi antara arah angin, kecepatan angin, tinggi gelombang dan waktu air surut untuk penyelamatan pantai di Florida tenggara dan kemudian membuat Lushine Rip current Scale (LURCS). kemudian, [6] melakukan penelitian di Central Florida bagian timur dan memodifikasi LURCS berdasarkan pengamatan bahwa kondisi gelombang lebih parah pada bagian pantai Florida tersebut dan periode gelombang memiliki peranan penting dan menamakannya East-Central Florida LURCS (ECFL LURCS). Arah gelombang selanjutnya menjadi peranan penting dalam ECFL LURCS. Hal ini ditemukan oleh [7] dalam penelitiannya di Pantai Daytona dan Pantai New Smyrna di Florida. Selanjutnya, [8] meneliti penggunaan LURCS yang telah dimodifikasi sebelumnya oleh [7] dengan menambahkan 2 pantai sebagai studi kasusnya. Pada penelitian yang dilakukan oleh [8], ditemukan hubungan antara kemunculan rip current dan keberadaan cuaca yang diikuti oleh angin kencang dan periode gelombang yang panjang. Menurut [9], ECFL LURCS masih kurang akurat, [9] menekankan bahwa kondisi lokal juga mendikte kemunculan rip current di pantai, dan teknik empiris seperti LURCS dan turunannya harus dikalibrasi secara lokal. Rip current di India telah diteliti oleh [2] dan menghilangkan faktor angin dalam LURCS karena kurangnya statistik dan bukti ilmiah yang mengaitkan angin dan kematian yang disebabkan rip current. Arah penyebaran gelombang dianggap mempunyai peranan penting dan menambahkannya ke dalam LURCS.

\section{METODE PENELITIAN}

Sistem ini mempunyai tujuan untuk memberikan informasi keamanan pantai dalam hal risiko rip current. Pengambilan keputusannya menggunakan decision tree yang dibangkitkan dengan algoritma C4.5. Pembangunan sistem dimulai dari pengumpulan data parameter risiko kemunculan rip current. Data non spasial yang dikumpulkan merupakan data ketinggian gelombang, periode gelombang, arah gelombang, penyebaran gelombang, dan tahap pasang surut.

Pembangkitan decision tree dilakukan dengan menggunakan algoritma C4.5. Selanjutnya, decision tree yang telah dibangkitkan diletakkan pada web client. Pada proses pengambilan keputusan risiko rip current, data parameter yang sama diambil dan kemudian menjadi masukan pada decision tree yang telah dibangkitkan sebelumnya. Hasil keluaran dari decision tree merupakan risiko rip current. Studi kasus yang dipilih adalah kondisi pantai yang ada disekitar Pulau Rote. Setelah proses pengambilan keputusan selesai, sistem akan masuk ke tahap pengujian. Pengujian sistem yang dilakukan adalah data dari hasil decision tree dibandingkan dengan data aslinya. kemudian dilakukan perhitungan untuk mengetahui nilai precision, accuracy, recall, dan F-measure dari decision tree yang telah dibangkitkan menggunakan algoritma C4.5 sebelumnya.

Menurut [10], terdapat sejumlah kekurangan dalam algoritma C4.5. Pertama, C4.5 menggunakan strategi divided, karena itu hasil akhirnya masih kurang optimal meskipun mempunyai akurasi yang tinggi. Kedua, kedalaman pohon dan jumlah node tidak dipertimbangkan, padahal kedalaman pohon berpengaruh pada kecepatan dan jumlah node

IJCCS Vol. 10, No. 2, July $2016: 195-206$ 
menunjukkan ukuran dari Decision Tree. Ketiga, saat membangun Decision Tree, sangat sulit untuk mengatur ulang isi di dalam tree. Keempat, efisiensi ujinya rendah.

\subsection{Analisis Kebutuhan Sistem}

Kebutuhan fungsional sistem pada penelitian ini adalah sebagai berikut:

1. Sistem dapat menyusun data kondisi pantai yang berasal dari database ke dalam format JSON.

2. Sistem dapat memproses data parameter rip current dalam format JSON untuk membangkitkan decision tree melalui algoritma C4.5.

3. Sistem dapat melakukan filtering risiko rip current pada peta sesuai dengan keinginan pengguna.

Sistem dapat melakukan pencarian pantai dan menampilkan kondisi serta risiko rip current yang terjadi di pantai tersebut. Dokumen masukan yang diperlukan oleh sistem dalam tahap pembangkitan adalah data parameter risiko rip current selama 3 tahun. Data parameter risiko rip current yang dimaksud adalah: tinggi gelombang laut, periode gelombang laut, arah gelombang laut, arah penyebaran, pasang surut laut, dan risiko rip current yang didapat dari lapangan.

Pada proses pengambilan keputusan risiko rip current, dokumen masukan berupa data non spasial parameter risiko rip current dalam format JSON. Selanjutnya, data tersebut menjadi masukan decision tree yang telah dibangkitkan sebelumnya. Data spasialnya berupa peta yang didapat dari Google Maps dan juga kordinat pantai untuk layering pada peta.

\subsection{Arsitektur Sistem}

Pada arsitektur sistem, terdapat aplikasi di sisi server yang bertugas melayani permintaan data dari web client. Dalam web client terdapat data non-spasial yang diterima akan diproses oleh decision tree sebelum menuju interface. Decision tree yang ada di dalam web client didapat dari hasil pembangkitan oleh algoritma C4.5. Ilustrasi arsitektur sistem dapat dilihat pada Gambar 1.

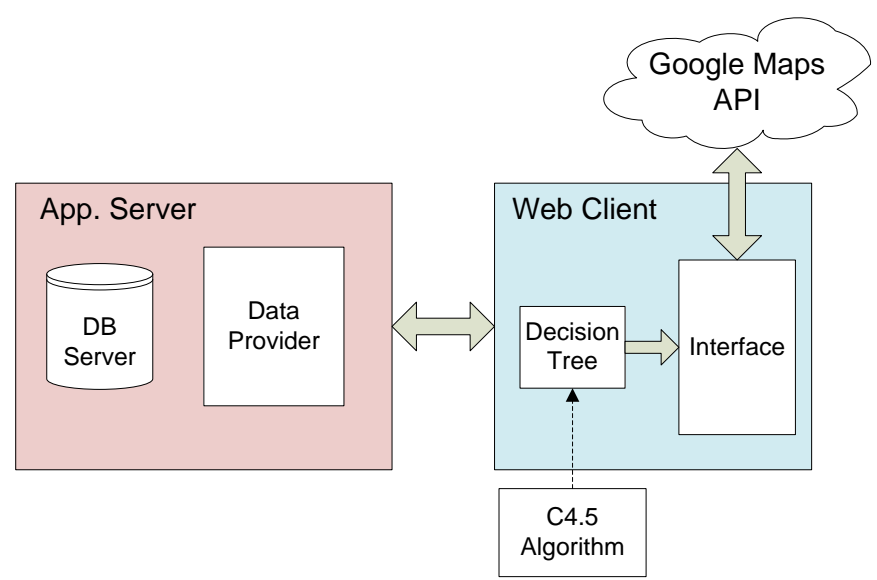

Gambar 1 Arsitektur sistem secara umum

Gambaran umum dalam sistem ini dimulai dari tahap pembangkitan decision tree. Data parameter risiko rip current dalam format JSON menjadi masukan untuk proses pembangkitan decision tree menggunakan algoritma C4.5. Kemudian hasil keluaran yang berupan decision tree tersebut ditanam pada sistem informasi geografis risiko rip current yang berinteraksi langsung dengan pengguna. Gambaran umum proses sistem dapat dilihat pada Gambar 2.

Pada tahap implementasi decision tree ke dalam SIG, data parameter rip current beserta kordinat pantai yang telah disusun dalam format JSON diambil dan menjadi masukkan untuk decision tree yang telah dibangkitkan dan ditanamkan. Data tersebut merupakan data nonspasial dari SIG. 


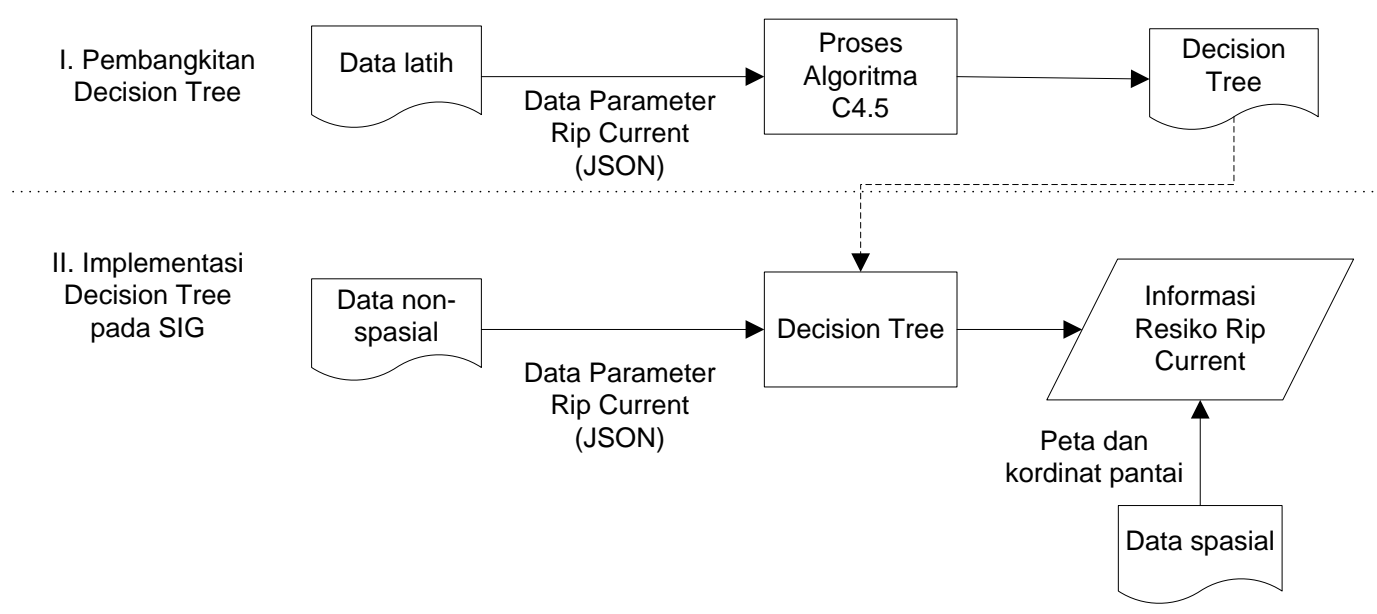

Gambar 2 Gambaran umum proses keseluruhan sistem

Pada tahap implementasi decision tree ke dalam SIG, data parameter rip current beserta kordinat pantai yang telah disusun dalam format JSON diambil dan menjadi masukkan untuk decision tree yang telah dibangkitkan dan ditanamkan. Data tersebut merupakan data nonspasial dari SIG. Peta beserta polyline yang merupakan data spasial dari SIG selanjutnya diambil. Data parameter rip current yang telah menjadi masukan decision tree akan diproses di dalamnya sehingga keluaran dari proses tersebut merupakan informasi risiko rip current yang akan ditampilkan pada antarmuka sistem. Dalam kurun waktu tertentu, evaluasi sistem dapat dilakukan dengan melakukan update pada data parameter rip current dan melakukan pembangkitan decision tree kembali berdasarkan data awal ditambah dengan data parameter terbaru.

\subsection{Rancangan Proses Pembangkitan Decision Tree}

Proses pembangkitan decision tree menggunakan algoritma C4.5 dimulai dengan mengumpulkan kasus-kasus berdasarkan rekam data yang tersedia. Setelah data terkumpul, jumlah kasus yang terjadi untuk setiap atribut yang ada mulai dihitung kemudian dituangkan ke dalam tabel. Contoh tabel kasus dapat dilihat pada Tabel 1.

Setelah tabel kasus didapat, perancangan pembangkitan decision tree menggunakan algortima C4.5 dilakukan. Algoritma C4.5 dirancang secara rekursif. Awalnya, dilakukan penghitungan untuk mencari nilai entropi pada seluruh dan setiap kasus. Kemudian mulai menghitung nilai gain dan dilakukan perhitungan split. Setelah itu, nilai gain ratio pada setiap kategori (atribut) dicari. Nilai gain ratio yang didapat dari setiap atribut kemudian dibandingkan. Nilai terbesar akan menjadi dasar kasus untuk perhitungan selanjutnya. Dasar kasus yang kasusnya hanya terdapat pada satu kategori risiko rip current langsung menjadi leaf node atau keputusan. Selain itu, dilakukan kembali perhitungan yang sama seperti awal.

Pada persamaan (1), nilai gain dari setiap atribut $\operatorname{gain}\left(C_{j}\right)$ didapat dari perhitungan entropi informasi total kasus (info(T)) dikurangi dengan entropi informasi setiap atribut yang bersangkutan $\left(\operatorname{info}\left(T, C_{j}\right)\right)$. Penghitungan entropi informasi dapat dilihat pada persamaan (2).

Penghitungan entropi informasi setiap atribut $\left(\operatorname{info}\left(C_{j}, T\right)\right)$ dapat dilihat pada persamaan (3). Setelah melakukan perhitungan-perhitungan tersebut, maka dilakukan perhitungan nilai split. Persamaan (4) menunjukkan penghitungan untuk mencari nilai split. Nilai split yang didapat akan menjadi masukan untuk mendapatkan rasio gain yang ditunjukkan pada persamaan (5). Gain ratio pada masing-masing atribut yang didapat akan menjadi perbandingan untuk mendapatkan dasar kasus untuk perhitungan selanjutnya. Rancangan diagram alir untuk proses pembangkitan decision tree menggunakan algoritma C4.5 dapat dilihat pada Gambar 3. Perhitungan ini akan terus berjalan hingga semuanya mendapatkan keluaran leaf node. 
Tabel 1 Contoh tabel kasus

\begin{tabular}{|c|c|c|c|c|c|}
\hline & \multicolumn{5}{|c|}{ Rip current Risk } \\
\hline & $\begin{array}{l}\text { TOTAL } \\
\text { KASUS }\end{array}$ & Very high & High & Moderate & Low \\
\hline TOTAL KASUS & 1092 & 17 & 452 & 605 & 18 \\
\hline \multicolumn{6}{|l|}{ Wave Height(m) } \\
\hline $\mathrm{WH}>2.0$ & 96 & 14 & 68 & 14 & 0 \\
\hline $1.5<\mathrm{WH}<=2.0$ & 171 & 3 & 104 & 64 & 0 \\
\hline $1.0<\mathrm{WH}<=1.5$ & 252 & 0 & 131 & 119 & 2 \\
\hline $0.5<\mathrm{WH}<=1.0$ & 439 & 0 & 129 & 297 & 13 \\
\hline $\mathrm{WH}<=0.5$ & 134 & 0 & 20 & 111 & 3 \\
\hline \multicolumn{6}{|l|}{ Wave Period(s) } \\
\hline $\mathrm{WP}>12$ & 0 & 0 & 0 & 0 & 0 \\
\hline $9<\mathrm{WP}<=12$ & 50 & 5 & 42 & 3 & 0 \\
\hline $6<\mathrm{WP}<=9$ & 338 & 12 & 184 & 141 & 1 \\
\hline $4<\mathrm{WP}<=6$ & 449 & 0 & 196 & 244 & 9 \\
\hline $\mathrm{WP}<=4$ & 255 & 0 & 30 & 217 & 8 \\
\hline \multicolumn{6}{|l|}{ Wave Direction(deg) } \\
\hline$-15<=\mathrm{WD}<=5$ & 272 & 0 & 115 & 157 & 0 \\
\hline $\begin{array}{l}(-25<=\mathrm{WD}<-15) \text { or }( \\
5<\mathrm{WD}<=10)\end{array}$ & 370 & 0 & 168 & 199 & 3 \\
\hline $\begin{array}{l}(-30<=\mathrm{WD}<-25) \text { or } \\
(10<\mathrm{WD}<=15)\end{array}$ & 187 & 0 & 67 & 119 & 1 \\
\hline $\begin{array}{l}(-35<=\mathrm{WD}<-30) \text { or }( \\
15<\mathrm{WD}<=20)\end{array}$ & 197 & 0 & 53 & 130 & 14 \\
\hline $\mathrm{WD}<-35$ or $\mathrm{WD}>20$ & 66 & 17 & 49 & 0 & 0 \\
\hline \multicolumn{6}{|l|}{ Directional spreading(deg) } \\
\hline $\mathrm{DS}<10$ & 0 & 0 & 0 & 0 & 0 \\
\hline $10<=\mathrm{DS}<20$ & 327 & 0 & 155 & 172 & 0 \\
\hline $20<=\mathrm{DS}<30$ & 509 & 7 & 167 & 320 & 15 \\
\hline $30<=\mathrm{DS}<40$ & 239 & 10 & 121 & 105 & 3 \\
\hline $\mathrm{DS}>=40$ & 17 & 0 & 9 & 8 & 0 \\
\hline \multicolumn{6}{|l|}{ Tidal Stage (m) } \\
\hline $\mathrm{TS}<=0.2$ & 674 & 12 & 341 & 318 & 3 \\
\hline $\mathrm{TS}>0.2$ & 418 & 5 & 111 & 287 & 15 \\
\hline
\end{tabular}

Pada Gambar 3, proses dimulai dari mengumpulkan kasus-kasus kemunculan rip current. Dari kasus yang dikumpulkan tersebut, dihitung nilai entropi untuk total kasus dan setiap atributnya, kemudian menghitung nilai gain, split, sehingga didapat nilai gain ratio untuk setiap atribut. Setelah setiap atribut memiliki gain ratio, maka dicari atribut dengan nilai gain ratio terbesar. Atribut dengan nilai gain ratio terbesar akan menjadi node tree. Kemudian, atribut dengan gain ratio terbesar dilihat setiap sub atributnya. Jika ada sub atribut yang kasus Jika tidak, maka proses diulang lagi tetapi dengan kasus yang berdasarkan sub atribut dari atribut dengan gain ratio terbesar. kemunculan rip current-nya hanya pada 1 kategori risiko 
kemunculan saja, maka pada sub atribut tersebut memiliki keputusan pada kategori risiko tersebut. Jika ada sub atribut yang masih terdapat lebih dari 1 kategori, maka proses diulang lagi tetapi dengan kasus yang berdasarkan sub atribut dari atribut dengan gain ratio terbesar. Proses tersebut akan terus berulang hingga setiap node memiliki keputusan. Rumus untuk $\operatorname{gain}\left(C_{j}\right)$

$$
\operatorname{gain}\left(C_{j}\right)=\operatorname{info}(T)-\operatorname{info}\left(T, C_{j}\right)
$$

dimana rumus info(T)

$$
\operatorname{info}(T)=-\sum_{j=1}^{N \text { Class }} \frac{\operatorname{freq}\left(C_{j}, T\right)}{|T|} \times \log \left(\frac{\operatorname{freq}\left(C_{j}, T\right)}{|T|}\right)
$$

dan untuk rumus info $\left(T, C_{j}\right)$

$$
\operatorname{info}\left(T, C_{j}\right)=\sum_{i=1}^{s} \frac{\left|T_{i}\right|}{|T|} \operatorname{info}\left(T_{i}\right)
$$

kemudian dilakukan perhitungan $\operatorname{split}\left(C_{j}\right)$

$$
\operatorname{split}\left(C_{j}\right)=-\sum_{i=1}^{s} \frac{\left|T_{i}\right|}{|T|} \log \frac{\left|T_{i}\right|}{|T|}
$$

untuk mencari rasio dari gain,

$$
\operatorname{gain\_ ratio}\left(C_{j}\right)=\frac{\operatorname{gain}\left(C_{j}\right)}{\operatorname{split}\left(C_{j}\right)}
$$

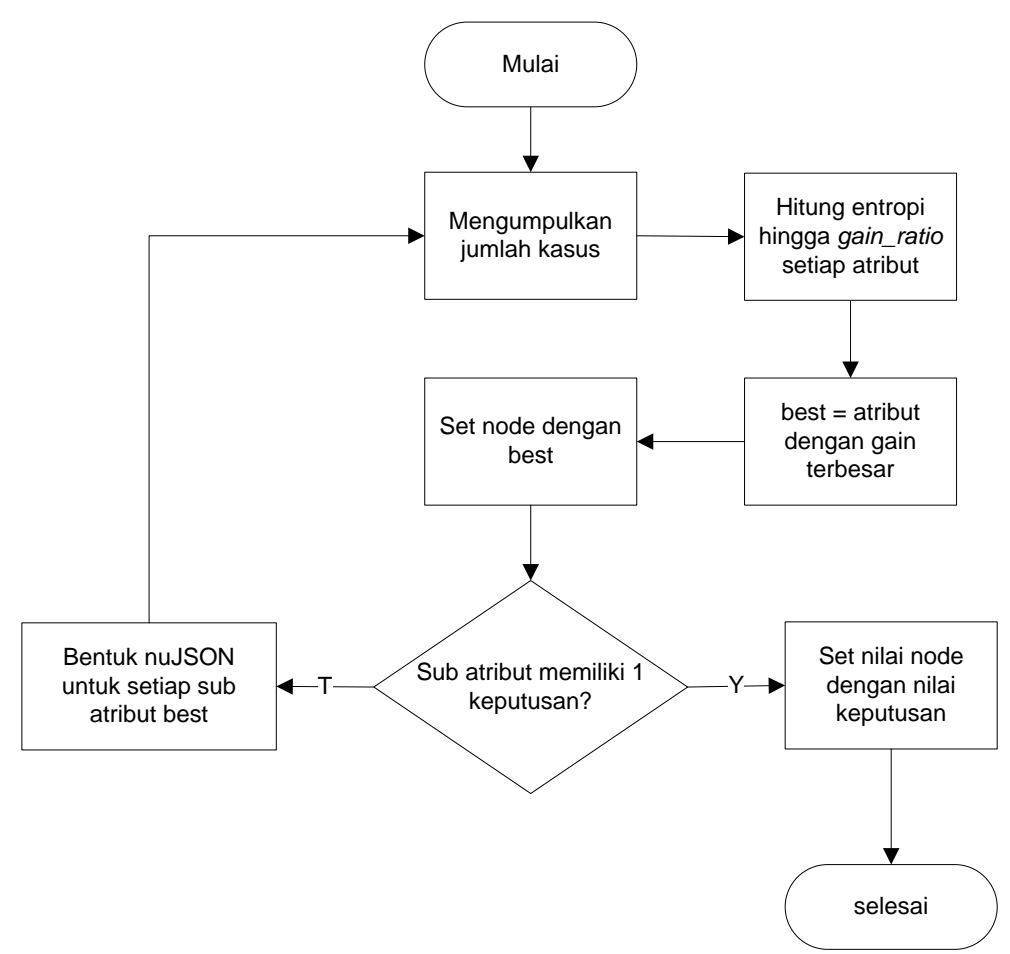

Gambar 3 Diagram alir untuk pembangkitan decision tree 


\subsection{Rancangan SIG}

Pada rancangan SIG, dilakukan pendekatan konsep reverse ajax dengan metode long polling. Tujuan penggunaan pendekatan ini adalah melakukan update pada interface web ketika terdapat perubahan atau update data pada server dalam jeda waktu yang mendekati real-time. Metode long polling adalah ajax yang melakukan request dan respond seperti ajax lainnya. Hal yang membedakan long polling dengan metode ajax lainnya adalah respond yang diberikan dari server ke client berdasarkan perubahan data yang terjadi yang artinya, server tidak akan mengirimkan respond sebelum ada perubahan data. Model ilustrasi long polling dapat dilihat pada Gambar 4.

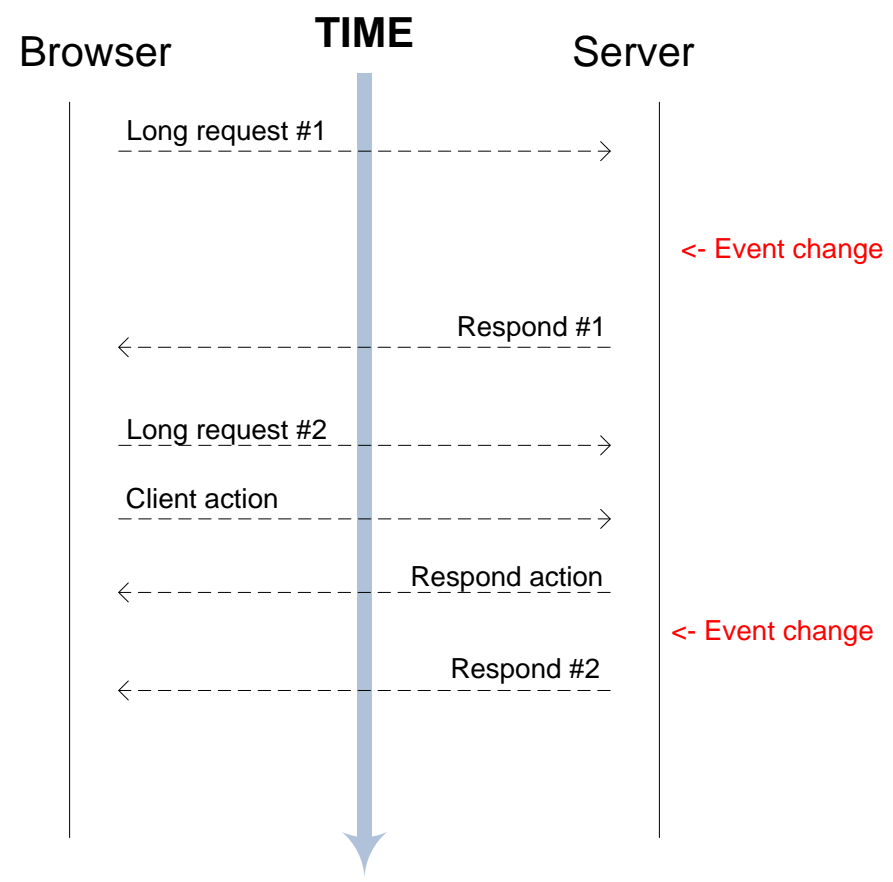

Gambar 4 Model ilustrasi long polling

Rancangan SIG dimulai dengan pembangunan proses long polling dari sisi server dan client, memasang decision tree yang telah dibangkitkan pada proses pembangkitan yang menggunakan algoritma C4.5 pada sisi client, dan mengambil peta dari server. Data non-spasial untuk SIG berupa data tinggi gelombang laut, periode gelombang laut, arah gelombang laut, arah penyebaran dan pasang surut laut. Data-data tersebut disimpan didalam database yang kemudian diambil dan direpresentasikan dalam bentuk dokumen JSON. Dokumen ini kemudian masuk ke proses pengambilan keputusan yang ada di dalam decision tree yang telah dibangun sebelumnya. Sedangkan untuk data kordinat pantai akan menjadi representasi dari polyline garis-garis pantai pada peta. Hasil keluarannya berupa risiko rip current yang sesuai dengan kondisi tersebut dan ditampilkan dilayar beserta peta lokasi pantai tersebut.

Pada sisi client, terdapat proses yang melakukan request data spasial ke Google API. Data tersebut akan disesuaikan dengan data pantai dan risiko rip current. Desain proses tampilan dapat ditunjukkan pada Gambar 5. 


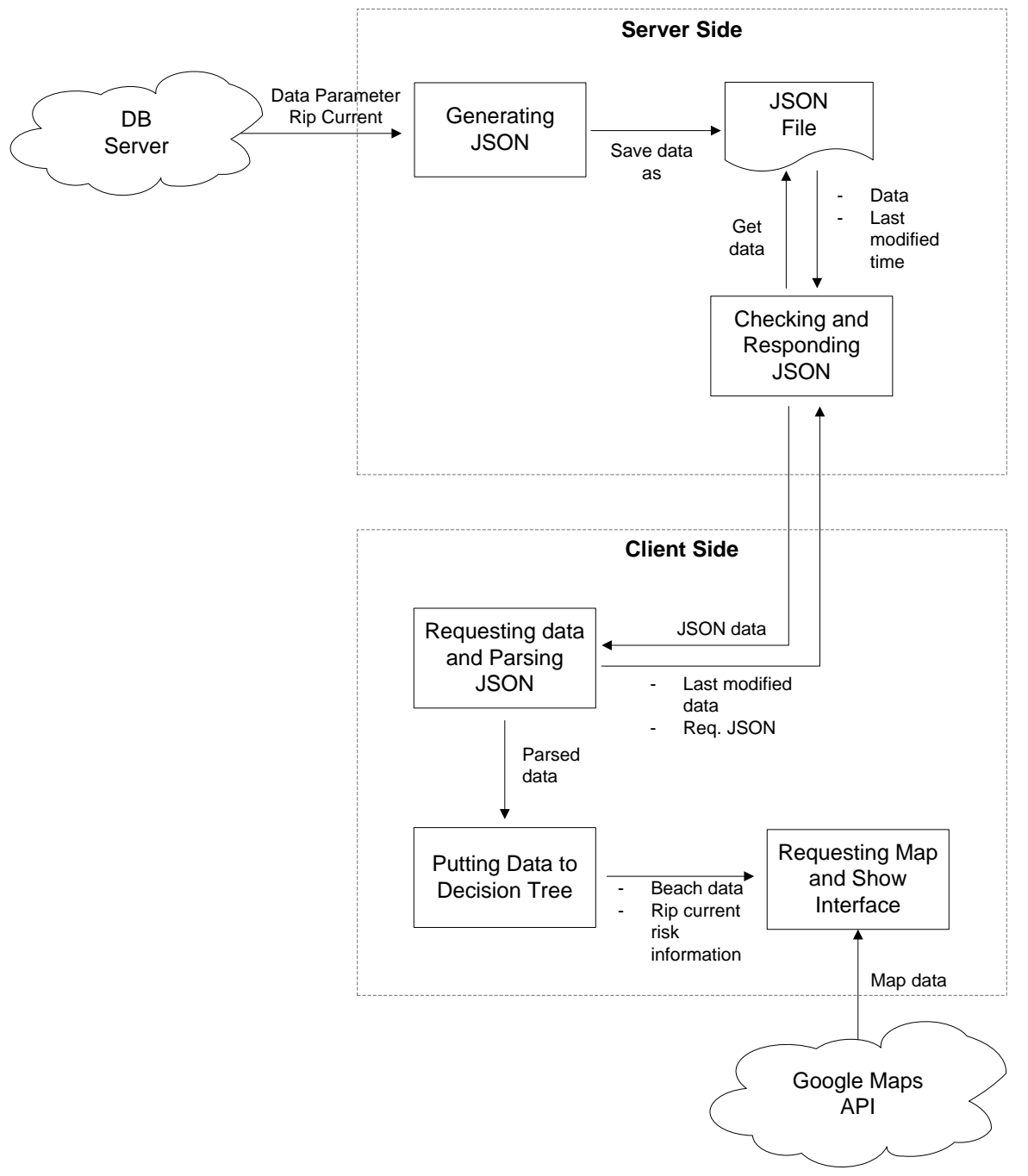

Gambar 5 Desain proses SIG

Saat data pantai dan risiko rip current sudah diterima, dilakukan konfigurasi untuk pemetaan. Kemudian, peta yang telah dikonfigurasi dimunculkan ke layar. Pengguna sistem dapat melakukan interaksi seperti mencari lokasi pantai dan peta yang ada pada layar akan langsung menunjukkan pantai yang dicari beserta informasi dari pantai tersebut. Selain melakukan pencarian, pengguna juga bisa melakukan filtering risiko rip current. Peta akan memperlihatkan pantai mana saja yang mempunyai risiko rip current sesuai dengan filtering yang dilakukan sebelumnya.

\subsection{Rancangan Evaluasi Pengujian}

Evaluasi pengujian dilakukan dengan cara menguji informasi rip current yang diprediksi oleh sistem terhadap informasi rip current yang terjadi di lapangan. Pengujian tersebut meliputi pencarian nilai Accuracy, Precision, Recall, dan F-measure pada sistem. Terdapat beberapa modifikasi untuk menyesuaikan jumlah risiko rip current yang kategorinya terbagi menjadi 4. Persamaaan tersebut dapat dilihat pada persamaan (6), (7), (8). Persamaan untuk menghitung accuracy menjadi:

$$
\text { Accuracy }=\frac{1}{4} \sum_{i=1}^{4} \frac{T P_{i}+T N_{i}}{\text { Total }_{i}}
$$

Persamaan untuk mencari nilai precision dan recall juga mengalami modifikasi menjadi: 


$$
\begin{aligned}
& \text { Precision }=\frac{1}{4} \sum_{i=1}^{4} \frac{T P_{i}}{P P_{i}} \\
& \text { Recall }=\frac{1}{4} \sum_{i=1}^{4} \frac{T P_{i}}{T P_{i}+F N_{i}}
\end{aligned}
$$

\section{HASIL DAN PEMBAHASAN}

\subsection{Tampilan sistem}

Terdapat beberapa fitur dalam sistem yang telah dibangun. Gambar 6 memperlihatkan tampilan sistem saat pertama kali dibuka.

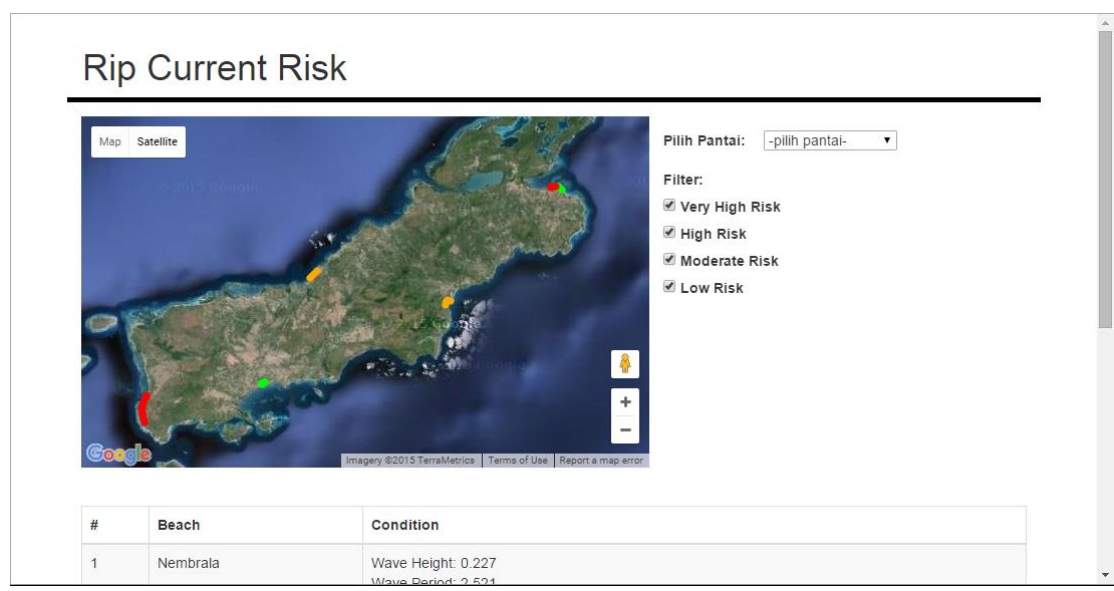

Gambar 6 Halaman sistem ketika pertama kali dibuka

Pada Gambar 6, dapat dilihat terdapat peta pada sisi kiri. Sisi kanan dari tampilan tersebut berisi input untuk filtering dan pencarian pantai. Pada peta, garis-garis pantai diberi polyline berwarna untuk menunjukkan posisi pantai. Warna merah menunjukkan risiko yang sangat tinggi (very high risk), oranye untuk risiko tinggi (high risk), hijau untuk risiko sedang (moderate risk), dan biru untuk risiko rendah (low risk). Gambar 7 menunjukkan input pantai yang telah dipilih.

Rip Current Risk

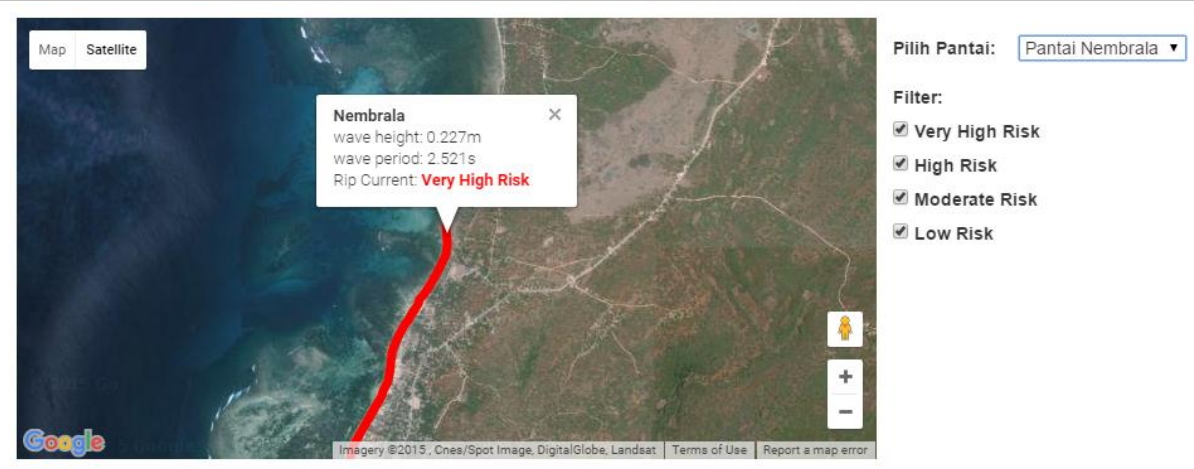

Gambar 7 Contoh menggunakan pencarian pantai

Pencarian pantai dapat dilakukan dengan memilih daftar pantai yang terdapat pada dropdown box dengan label "Pilih Pantai". Ketika input pantai dipilih, peta akan langsung mengarah ke pantai tersebut dan memunculkan informasi dari pantai tersebut.

Proses filtering pantai dapat dilihat pada Gambar 8. Sistem akan memunculkan pantai mana saja yang sesuai dengan risiko yang dipilih. Filtering pada pantai dilakukan dengan memberikan centang pada input. Pantai lainnya yang tidak dicentang, tidak akan dimunculkan 
pada peta. Pada Gambar 8, risiko yang dipilih adalah high risk, maka pantai-pantai yang memiliki risiko tersebut yang akan dimunculkan pada peta.

\section{Rip Current Risk}

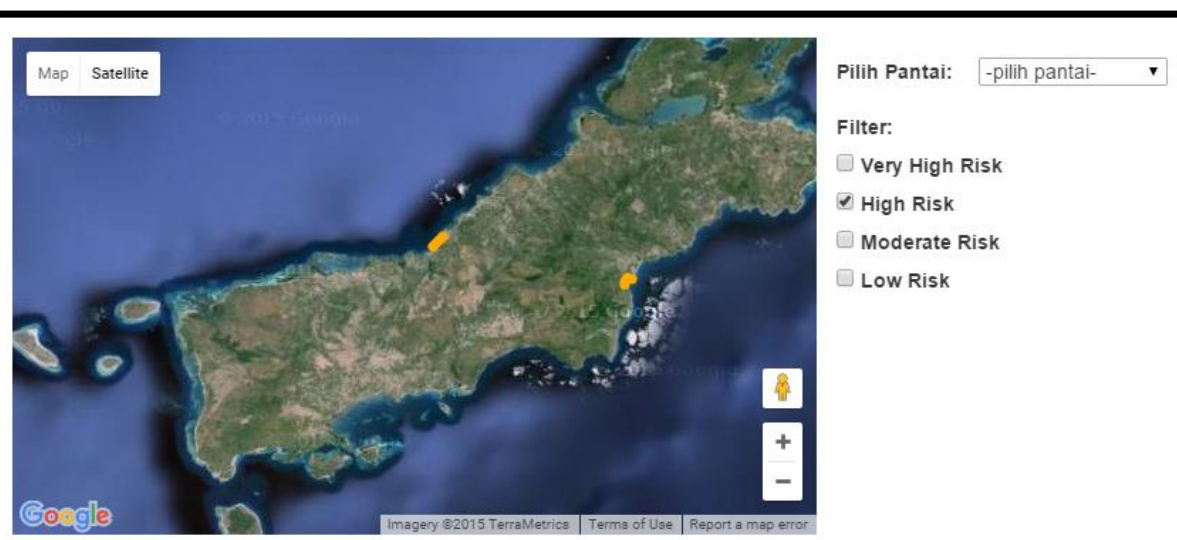

Gambar 8 Contoh penggunaan fitur filtering risiko rip current

\subsection{Hasil pengujian accuracy, precision, recall, dan F-measure}

Pengujian dilakukan dengan membuat tabel confusion matrix untuk masing - masing risiko rip current. Kemudian mulai dilakukan penghitungan accuracy, precision, recall, dan $F$ measure. Nilai accuracy dari masing - masing kategori dan rata - rata keseluruhan kategori ditunjukan pada Tabel 2.

Tabel 2 Nilai accuracy dari hasil decision tree C4.5

\begin{tabular}{|l|r|}
\hline \multicolumn{1}{|c|}{ Risiko } & \multicolumn{2}{c|}{ Accuracy } \\
\hline Very high & 0,69 \\
\hline High & 0,71 \\
\hline Moderate & 0,95 \\
\hline Low & 0,99 \\
\hline Rata-rata & 0,84 \\
\hline
\end{tabular}

Nilai precision dari masing - masing kategori dan rata - rata keseluruhan kategori ditunjukan pada Tabel 3.

Tabel 3 Nilai precision dari hasil decision tree C4.5

\begin{tabular}{|l|r|}
\hline \multicolumn{1}{|c|}{ Risiko } & \multicolumn{1}{c|}{ Precision } \\
\hline Very high & 0,070 \\
\hline High & 0,98 \\
\hline Moderate & 0,89 \\
\hline Low & 0,5 \\
\hline Rata-rata & 0,61 \\
\hline
\end{tabular}

Nilai recall dari masing - masing kategori dan rata - rata keseluruhan kategori ditunjukan pada Tabel 4.

Tabel 4 Nilai recall dari hasil decision tree $\mathrm{C} 4.5$

\begin{tabular}{|l|r|}
\hline \multicolumn{1}{|c|}{ Risiko } & \multicolumn{1}{c|}{ Recall } \\
\hline Very high & 0,53 \\
\hline High & 0,59 \\
\hline Moderate & 0,91 \\
\hline Low & 0,75 \\
\hline Rata-rata & 0,69 \\
\hline
\end{tabular}


Setelah mendapatkan nilai accuracy, precision, dan recall, nilai precision dan recall dapat digunakan secara bersama - sama dengan menggabungkannya dalam $F$-measure. Nilai $F$ measure menunjukkan rata - rata harmonis antara precision dan recall.

Nilai $F$-measure dari masing - masing kategori dan rata - rata keseluruhan kategori ditunjukan pada Tabel 5.

Tabel 5 Nilai F-measure pada masing - masing kategori

\begin{tabular}{|l|r|}
\hline \multicolumn{1}{|c|}{ Risiko } & F-measure \\
\hline Very high & 0,12 \\
\hline High & 0,73 \\
\hline Moderate & 0,90 \\
\hline Low & 0,6 \\
\hline Rata-rata & 0,59 \\
\hline
\end{tabular}

Dari Tabel 5 dapat dilihat nilai F-measure pada kategori very high merupakan nilai yang terendah daripada kategori lainnya. Hal ini disebabkan oleh nilai precision pada kategori very high relatif kecil. Namun, nilai rata - rata accuracy hasil dari decision tree $\mathrm{C} 4.5$ memiliki nilai yang cukup tinggi yaitu 0,84 dari rentang nilai 0 hingga 1 . Semakin besar nilai accuracy tersebut, maka sistem semakin akurat.

\subsection{Pengujian waktu proses}

\subsubsection{Waktu proses pembangkitan decision tree}

Pengujian waktu proses pembangkitan decision tree menggunakan algoritma C4.5 dilakukan secara offline. Dari eksperimen didapat waktu proses pembangkitan decision tree menggunakan algoritma $\mathrm{C} 4.5$ dari awal hingga menghasilkan decision tree memerlukan waktu 253ms dengan data kasus yang diproses sebanyak 1092 kasus.

\subsubsection{Waktu proses memuat website SIG}

Pengujian waktu proses memuat website dilakukan secara online. Layanan web server yang digunakan adalah Google App Engine. Waktu proses memuat website yang telah ditanamkan decision tree $\mathrm{C} 4.5$, dari pemanggilan website hingga penampilan informasi risiko kemunculan rip current, memerlukan waktu 6,04s. Waktu proses ini bisa berubah-ubah karena tergantung dengan koneksi internet yang tersedia.

\section{KESIMPULAN}

Berdasarkan hasil penelitian yang telah dilakukan, dapat disimpulkan bahwa:

1. Sistem Informasi Geografis Risiko Kemunculan Rip current dapat dibangun dengan menggunakan decision tree yang dibangkitkan dengan menggunakan algoritma C4.5 berdasarkan data parameter ketinggian gelombang laut, periode gelombang laut, arah gelombang laut, arah penyebaran, dan pasang surut laut untuk mendapatkan informasi risiko kemunculan rip current.

2. Dengan data parameter yang digunakan untuk membangkitkan decision tree menggunakan algoritma $\mathrm{C} 4.5$ dan menguji decision tree tersebut, didapatkan nilai rata rata untuk accuracy sebesar 0,84 , nilai rata - rata untuk precision sebesar 0,61 , nilai rata - rata untuk recall sebesar 0,69, dan nilai rata - rata F-measure yang didapat sebesar 0,59 . Nilai - nilai tersebut pada kategori very high masih cenderung kecil, yang artinya 
keakuratan decision tree C4.5 masih kurang akurat. Hal ini disebabkan oleh kurangnya kasus kemunculan rip current pada kategori very high.

3. Waktu proses pembangkitan decision tree menggunakan algoritma $\mathrm{C} 4.5$ mulai dari menjalankan program hingga menampilkan decision tree diproses dalam waktu $253 \mathrm{~ms}$ dengan data parameter yang digunakan sebanyak 1092 kasus. Sedangkan, waktu proses memuat website mulai dari pemanggilan website hingga penampilan informasi secara relatif diproses dalam waktu $6,04 \mathrm{~s}$.

\section{SARAN} antara lain:

Dari penelitian yang dilakukan, adapun saran untuk perbaikan penelitian lebih lanjut

1. Sistem Informasi Geografis Pemantauan Risiko Kemunculan Rip current pada penelitian ini perlu ditingkatkan lagi nilai precision dan recall-nya. Peningkatan nilai - nilai tersebut berhubungan dengan data parameter yang digunakan agar lebih disesuaikan lagi. Jumlah kasus juga perlu ditambah agar akurasi sistem meningkat.

2. Kemunculan rip current juga dipengaruhi oleh kondisi geografi sekitar pantai dimana sistem akan memerlukan kombinasi dengan metode lain yang berhubungan dengan struktur tanah dan kondisi geografi lainnya.

\section{DAFTAR PUSTAKA}

[1] Short, A.D., dan Hogan, C.L., 1994, Rip Currents and Beach Hazards: Their Impact on Public Safety and Implications for Coastal Management, J Coast Res SI12, 197-209.

[2] Kumar, A., dan Prasad, 2014, Rip current-related fatalities in India: a new predictive risk scale for forecasting rip currents, Nat Hazards 70, 313-335

[3] Quinlan, J.R., 2006, Bagging, Boosting, and C4.5, http://www.cs.ecu.edu/ dingq/CSCI6905/readings/BaggingBoosting.pdf, diakses tanggal 24 Desember 2012, 10:38

[4] Quinlan, J.R., 2006, Improved Use of Continuous Attributes in C4.5, http://arxiv.org/pdf/cs/9603103.pdf, diakses tanggal 24 Desember 2012, 10:36.

[5] Lushine, J., 1991 Rip Currents: Human Impact and Forecastability. In: Proceedings of the coastal zone, ASCE, New York, 3558-3569.

[6] Lascody, R., 1998, East Central Florida Rip Current Program, National Weather Dig 22, 25-30.

[7] Engle, J., 2003, Formulation of A Rip Current Forecasting Technique Through Statistical Analysis of Rip Currentrelated Rescues, Tesis, University of Florida, Gainesville.

[8] Schrader, M., 2004, Evaluation of The Modified ECFL LURCS Rip Current Forecasting Scale and Conditions of Selected Rip Current Events in Florida, Tesis, University of Florida, Gainesville.

[9] Nelko, V. dan Dalrymple R.A., 2008, Rip Currents: Mechanisms and Observations, Smith $J M(E d)$ Proceedings Of The 31st International Conference On Coastal Engineering, Singapore, September 5.

[10] Rui, L., Xian-mei, W., dan Xue-wei, Y., 2009, The Improvement of C4.5 Algorithm and Case Study, IEEE, p.190-192, http://originwww.computer.org/plugins/dl/pdf/proceedings/iscid/2009/3865/02/3865b190.pdf, diakses tanggal 01 Desember 2012, 15.24 